\title{
Tingkat Persepsi Mahasiswa Terhadap Kota Jambi Sebagai Kawasan Tanpa Asap Rokok (Peraturan Daerah Nomor 3 Tahun 2017)
}

\author{
Supeno*, Fachruddin Razi, Mhd. Ansori, Dedy Syaputra \\ Fakultas Hukum Universitas Batanghari Jambi \\ Jl. Slamet Riyadi Broni Jambi \\ *Correspondence email: supeno@unbari.ac.id
}

\begin{abstract}
Abstrak. Kawasan Tanpa Rokok mengatur bahwa kawasan tanpa rokok meliputi tempat umum, tempat kerja, tempat ibadah, tempat bermain, kendaraan umum, lingkungan proses belajar mengajar, sarana kesehatan dan sarana olahraga, akan tetapi dalam kenyataannya masih banyak orang yang melanggar ketentuan tersebut termasuk kalangan terdidik seperti dosen, guru, mahasiswa dan sebagainya. Tujuan dari penelitian ini adalah untuk mendapatkan informasi tentang tingkat persepsi masyarakat terdidik terhadap Kota Jambi sebagai kawasan tanpa rokok dan ingin mengukur peran serta masyarakat terdidik menjadikan Kota Jambi sebagai kawasan tanpa rokok Tipe penelitian yang digunakan adalah penelitian empiris yaitu dengan cara melakukan penelitian langsung ke lapangan, sebagai sumber data primer adalah sumber data yang diperoleh dari hasil wawancara dengan sampel terpilih dan sedangkan yang menjadi sumber data sekunder adalah buku dan jurnal dan hasil penelitian lainnya, pendekatan yang digunakan adalah pendekatan sociological aspec yaitu untuk mengungkap gejala-gejala dan fenomena social yang terjadi di lapangan, sedangkan teknik pengumpulan data yang digunakan adalah teknik wawancara (interview), teknik penarikan sampel dilakukan secara random sampling dan purposive sampling, data yang digunakan adalah data qualitative, hasil penelitian menunjukkan bahwa tingkat pengetahuan mahasiswa tentang kota Jambi sebanagi kawasan tanpa rokok adalah cukup baik dan optimis terhadap pemberlakuan Kota Jambi sebagai kawasan tanpa asap rokok.
\end{abstract}

Kata kunci: rokok; persepsi; mahasiswa

Abstract. Non-Smoking Areas stipulates that non-smoking areas include public places, workplaces, places of worship, playgrounds, public transportation, teaching and learning process environments, health facilities and sports facilities, but in reality there are still many people who violate these provisions, including educated circles such as lecturers, teachers, students and so on. The purpose of this study was to obtain information about the level of educated people's perceptions of Jambi City as a smoke-free area and want to measure the participation of educated people in making Jambi City a smoke-free area. as the primary data source is the source of data obtained from interviews with selected samples and while the secondary data sources are books and journals and other research results, the approach used is the sociological aspect approach, namely to reveal social phenomena and phenomena that occur in the community. the field, while the data collection technique used is interview technique, the sampling technique is done by random sampling and purposive sampling, the data used is qualitative data, the results of the study show that the level of student knowledge Wa about Jambi City as a smoke-free area is quite good and optimistic about the implementation of Jambi City as a smoke-free area.

Keywords: cigarettes; perception; student

\section{PENDAHULUAN}

Perilaku merokok merupakan suatu hal yang dianggap biasa oleh sebagian masyarakat Indonesia khususnya bagi kaum laki-laki dewasa, ${ }^{1}$ kebiasaan merokok pada umumnya telah dimulai sejak usia remaja, berdasarkan hasil riset Lembaga Penanggulangan Masalah Merokok (LM3) bahwa anak-anak Indonesia sudah mulai merokok pada usia 9 tahun. ${ }^{2}$ Dari data Susenas tahun 2001 diperoleh data usia mulai merokok di bawah usia 20 tahun mengalami trend yang meningkat, lebih dari separuh perokok mengkonsumsi lebih dari 10 batang per hari, usia 10-14 tahun sebesar

1 Triana Srisantyorini, F.Y. Sumartin. 2005. Perilaku Merokok Mahasiswa Universitas Muhammadiyah Jakarta dan Faktor-faktor yang Memperngaruhinya Tahun 2004. Jurnal Kedokteran dan Kesehatan UMJ. Juli 2005. Vol 1 No 2.

2 Komalasari D \& A.F. Helmi. 2006. Faktor-faktor Penyebab Perilaku Merokok Pada Remaja. 15 Januari 2008.
30,50\% mengkonsumsi lebih dari 10 batang per hari, 2,6 $\%$ mengkonsumsi 20 batang per hari. Tahapan-tahapan perilaku merokok diawali dari tahapan preparation berupa tahapan keinginan rasa tahu terhadap rokok. ${ }^{3}$

Berbagai macam alasan yang melatarbelakangi perilaku merokok, beberapa latar belakang merokok menurut Kurt Lewin adalah dari faktor individu dan lingkungan. Menurut Green perilaku merokok dipengaruhi oleh faktor; pendahulu (predisposing), yang meliputi pengetahuan, sikap, kepercayaan, keyakinan, tradisi, nilai; faktor pemungkin (enabling) yang meliputi ketersediaan sumber/fasilitas; dan faktor penguat (reinforcing) yang meliputi sikap dan perilaku orang di

3 Hilda Irianty, Ridha Hayati, Gambaran Perilaku Merokok Pada Mahasiswa Fakultas Kesehatan Masyarakat (FKM) di Kampus XXX, Jurnal Manusia dan Kesehatan, Vol.2 No.2, 2019, Hal.308 
sekitarnya. ${ }^{4}$ Dalam Health Believe Model perilaku seseorang ditentukan oleh motif dan kepercayaan. ${ }^{5}$

Dari segi pengguna rokok hampir semua profesi ada yang mengkonsumsi rokok baik dari kalangan buruh, petani, ulama, pelajar, mahasiswa termasuk yang berkerja di pemerintahan, walaupun yang paling dominan adalah yang berkerja sebagai buruh dan petani sebagai kelompok yang masuk dalam ruang lingkup tidak terdidik yang mungkin faktor sejarah mereka sangat minim mendapatkan pengetahuan tentang bahaya merokok dan merupakan bagian dari tradisi dan lingkungan. Akan tetapi bagi kalangan ulama, mahasiswa dan pemerintahan merupakan kalangan yang dapat dikategorikan sebagai kalangan terdidik akan tetapi perilaku merokok masih banyak terjadi di kalangan tersebut. Salah satu bagian dari kalangan terdidik adalah tenaga kesehatan, sebagai aktor penting terwujudnya derajat kesehatan yang baik.

Kota Jambi merupakan wilayah yang sudah memberlakukan Peraturan Daerah Tentang Kawasan Tanpa Rokok, dalam Pasal 7 Ayat 2 Peraturan Daerah Kota Jambi Nomor 3 Tahun 2017 Tentang Kawasan Tanpa Rokok mengatur bahwa kawasan tanpa rokok meliputi tempat umum, tempat kerja, tempat ibadah, tempat bermain, kendaraan umum, lingkungan proses belajar mengajar, sarana kesehatan dan sarana olahraga, akan tetapi dalam kenyataannya masih banyak orang yang melanggar ketentuan tersebut yang masih bebas merokok di kawasan larangan merokok tersebut. Dapat dirumuskan apa yang akan diteliti yaitu untuk mengukur tingkat pengetahuan dan persepsi mahasiswa terhadap pemberlakuan kawasan tanpa rokok di Kota Jambi.

Menurut pertimbangan $\mathrm{c}$ dan $\mathrm{d}$ Undang-Undang Nomor 36 Tahun 2009 Tentang Kesehatan dinyatakan bahwa setiap hal yang menyebabkan terjadinya gangguan kesehatan pada masyarakat Indonesia akan menimbulkan kerugian ekonomi yang besar bagi negara, dan setiap upaya peningkatan derajat kesehatan masyarakat juga berarti investasi bagi pembangunan negara; bahwa setiap upaya pembangunan harus dilandasi dengan wawasan kesehatan dalam arti pembangunan nasional harus memperhatikan kesehatan masyarakat dan merupakan tanggung jawab semua pihak baik Pemerintah maupun masyarakat. Di dalam pasal 115 Undang-Undang Nomor 36 Tahun 2009 juga diatur Kawasan Tanpa Rokok (KTR) yaitu:

1. Fasilitas pelayanan kesehatan;

2. Tempat proses belajar mengajar;

3. Tempat anak bermain;

4. Tempat ibadah;

5. Angkutan umum;

6. Tempat kerja; dan

4 Notoatmodjo. 2003. Pendidikan dan Perilaku Kesehatan. Rineka Cipta. Jakarta.

5 Ogden, Jane. 1996. Health Psychology, a tex book, Open University Press. Buckingham. Philadelphia.
7. Tempat umum dan tempat lain yang ditetapkan.

Salah satu hal yang menyebabkan terjadinya gangguan kesehatan bagi masyarakat Indonesia adalah kebiasaan merokok yang tidak terbantahkan secara medis dalam 1 (satu) batang rokok mengandung zat-zat yang berbahaya bagi tubuh manusia, bahkan dalam kemasan rokok tertulis "MEROKOK MEMBUNUHMU", dengan terganggunya kesehatan masyarakat akan membawa kerugian langsung bagi ekonomi masyarakat karena jika seseorang yang sudah mengalami gangguan kesehatan akibat merokok akan mengganggu aktivitas kerjanya dan cost yang harus dikeluarkan akan semakin meningkat pula. Dan ironisnya lagi hampir semua Kawasan Tanpa Rokok (KTR) ada orang yang merokok. Masalah rokok tidak hanya menjadi tanggung jawab pemerintah saja akan tetapi menjadi tanggung jawab seluruh lapisan masyarakat, tanpa adanya sinergi yang baik antara pemerintah dan masyarakat dalam menangani permasalahan rokok maka tidak akan tercapai upaya peningkatan derajat kesehatan masyarakat yang diusung oleh pemerintah melalui Kementerian Kesehatan.

Pemerintah Kota Jambi telah memberlakukan Peraturan Daerah (Perda) Nomor 3 Tahun 2017 Tentang Kawasan Tanpa Rokok (KTR), dalam Peraturan Daerah tersebut diatur bahwa tujuan pengaturan Kawasan Tanpa Rokok (KTR) adalah untuk mewujudkan ruang dan lingkungan yang bersih dan sehat; memberikan perlindungan kepada masyarakat dari dampak buruk rokok baik langsung maupun tidak langsung; menciptakan kesadaran masyarakat untuk hidup sehat; dan melarang produksi, penjualan, iklan, promosi dan/atau penggunaan rokok di KTR.

Dengan diberlakukannya Peraturan Daerah Nomor 3 Tahun 2017 ini Pemerintah Kota Jambi memiliki komitmen untuk menjadikan beberapa kawasan menjadi kawasan Tanpa Rokok (KTR) sebagaimana yang diamanatkan Pasal 115 Undang-Undang Nomor 36 Tahun 2009 Tentang Kesehatan, akan tetapi komitmen saja tidak cukup dan harus diimplementasikan dalam bentuk real action. Perda ini harus didukung secara penuh dari semua kalangan masyarakat, masyarakat harus berada di garda terdepan dalam menanamkan edukasi kepada masyarakat untuk tidak merokok terutama di kawasan-kawasan tertentu, upaya ini akan mengalami kegagalan jika masyarakat masih menjadi aktor dalam merokok, oleh karena itu bagi masyarakat yang masih merokok untuk segera "stop merokok" salah satu unsur masyarakat terdidik adalah mahasiswa, kedudukan mahasiswa sangat penting dalam mensukseskan perda ini karena:

1. Mahasiswa merupakan tenaga terdidik yang mengetahui tentang bahaya merokok;

2. Mahasiswa merupakan elemen masyarakat merupakan yang beraktifitas dalam kawasan larangan 
merokok sebagaimana diatur dalam Pasal 115 Undang-Undang Nomor 36 tahun 2009;

3. Mahasiswa merupakan unsur masyarakat yang memiliki tanggung jawab penuh untuk tercapainya peningkatan derajat kesehatan masyarakat.

Hampir semua mahasiswa memahami tentang bahaya merokok karena sebelumnya telah mendapatkan edukasi dari pendidikan, akan tetapi dalam praktiknya masih banyak mahasiswa yang melanggar kawasan tanpa rokok. Berbagai macam alasan yang membuat mereka tidak berhenti merokok seperti rokok dapat membantu dalam menghadapi masalah, rokok dapat meningkatkan konsentrasi kuliah, relaksasi, mengurangi ketegangan dan sebagainya.

Kesulitan yang dihadapi oleh perokok untuk berhenti merokok merupakan suatu keadaan "tobacco dependency" atau ketergantungan terhadap rokok, ketergantungan terhadap rokok menjadikan perokok mengabaikan dan tidak peduli dengan informasi tentang bahaya rokok dan aturan tentang kawasan tanpa rokok, hal ini sebenarnya dapat dilakukan jika perokok memiliki niat/keinginan yang kuat untuk berhenti merokok, tidak ada suatu urusan termasuk yang berat tidak dapat diatasi kecuali dilakukan dengan niat/goorwill yang kuat dan diikuti dengan upaya yang sungguh-sungguh melalui tahapan-tahapan yang dapat dilakukan baik secara medis maupun nonmedis. Langkah pertama yang dapat segera dilakukan adalah tidak mengkonsumsi rokok di tempat-tempat yang dilarang untuk merokok terutama pada saat sedang melaksanakan tugas sebagai tenaga kesehatan, dan merokok hanya dapat dilakukan di tempat merokok/smooking area. Selanjutnya perokok harus memiliki kepedulian terhadap lingkungan bahwa asap rokok membawa efek negatif bagi orang lain terutama bagi keluarga sendiri jika merokok dilakukan di lingkungan rumah sendiri, di sisi lain agama Islam memerintahkan agar kita melakukan hal yang baik-baik dan menjauhkan diri dari hal-hal yang buruk dan keburukan rokok bagi kesehatan telah terbukti secara medis.

\section{METODE \\ Tipe Penelitian}

Penelitian ini menggunakan tipe penelitian empiris sebagai konsekuensi pemilihan topik yang akan dikaji dalam penelitian maka tipe penelitian yang digunakan adalah penelitian empiris, yakni penelitian yang difokuskan untuk mengkaji secara langsung kepada objek penelitian yaitu para kalangan terdidik di Kota Jambi.

\section{Pendekatan Penelitian}

Pendekatan penelitian yang akan digunakan dalam penelitian ini adalah sociological aspec, yaitu untuk menggali informasi yang sedalam-dalamnya gejala- gejala kehidupan sosial yang berkaitan dengan tingkat persepsi masyarakat terhadap kawasan tanpa asap rokok di Kota Jambi.

\section{Sumber data \\ Penelitian lapangan (field research)}

Yaitu dengan cara melakukan penelitian langsung ke narasumber, dengan demikian akan diperoleh informasi yang akurat dan objektif tentang objek yang akan diteliti

\section{Penelitian kepustakaan (library research)}

Penelitian kepustkaan dimaksudkan agar penelitian lapangan yang telah dilakukan dapat diperkuat oleh arguen-argumen hukum dan teori oleh para ahli yaitu dengan cara menelaah peraturan perundangundangan maupun berbagai macam sumber buku yang memiliki keterkaitan dengan penelitian yang dilakukan yang memiliki keterkaitan secara langsung dengan penelitian terutam yang bersumber dari buku dan jurnal ilmiah yang terakreditasi sehingga konsep dan informasinya dapat dipertanggungjawabkan.

\section{Teknik penarikan sampel}

Dalam penelitian ini teknik pengumpulan data yang dilakukan adalah secara random sampling dan purposive sampling yaitu dengan memilih narasumber yang memiliki kapasitas dan kapabilitas dalam permasalahan yang dibahas dalam penelitian sehingga akurasi dan validasi data dan informasi yang ingin diperoleh benar-benar dapat dipertanggungjawabkan.

\section{Teknik pengumpulan data}

Teknik pengumpulan data yang dilakukan adalah dengan cara wawancara langsung mengajukan berbagai macam pertanyaan yang sudah disiapkan oleh tim peneliti yang disusun secara sistematis dan terukur untuk memperoleh jawaban- jawaban atas informasi yang ingin diperoleh yaitu tentang objek yang diteliti, data yang telah diperoleh akan diseleksi dan ada hubungan dengan permasalahan tersebut diklasifikasi sesuai dengan tingkat relevansinya.

\section{Analisis data}

Data yang diperoleh kemudian dianalisis dan dikaji dan menarik kesimpulan dari semua permasalahan yang dibahas secara qualitatif, kajian dilakukan sedemikian rupa sehingga menggambarkan permasalahan dan pemecahannya secara jelas dan komprehensif.

\section{HASIL DAN PEMBAHASAN}

Dalam penelitian ini yang menjadi sasaran/responden adalah mahasiswa aktif yang ada di Kota Jambi dari berbagai macam perguruan tinggi yang ada, mahasiswa merupakan bagian dari remaja atau 
adolesen, ${ }^{6}$ masa ini merupakan masa keemasan bagi manusia karena mahasiswa merupakan fase penting untuk menjadi manusia dewasa dan sangat menentukan masa depannya di fase ini.

Data mahasiswa yang berhasil dijadikan responden dalam penelitian ini adalah sebagai berikut:

Jumlah mahasiswa yang memberi respon: 322 mahasiswa

Jumlah perguruan tinggi: 12 Perguruan Tinggi

Data perguruan tinggi yang telah memberikan respon dan mengirimkan jawabannya adalah sebagai berikut:

1. Universitas Negeri Jambi;

2. Universitas Islam Negeri Sultan Thaha Saifuddin Jambi

3. Universitas Batanghari Jambi

4. Universitas Muhammadiyah Jambi

5. Universitas Dinamika Bangsa

6. Universitas Nurdin Hamzah

7. Universita Terbuka (UT) Jambi

8. Sekolah Tinggi Ilmu Kesehatan harapan Ibu Jambi

9. Politeknik Negeri Padang

10.Politeknik Kesehatan Jambi

11. Sekolah Tinggi Management Komputer

12.Akademi Analis Kesehatan jambi

Adapun pertanyaan yang diajukan kepada mahasiswa adalah sebagai berikut:

1. Apakah saudara mengetahui tentang Peraturan Daerah Kota Jambi yang mengatur tentang kawasan tanpa rokok?

2. Apakah saudara mengetahui kawasan apa saja yang diatur dalam Peraturan daerah Kota Jambi Nomor 3 tahun 2017?

3. Apakah saudara mengetahui bahwa salah satu kawasan tanpa rokok yang diatur dalam peraturan Daerah Nomor 3 Tahun 2017 adalah Lingkungan Tempat Belajar Mengajar?

4. Apakah saudara merespon dengan positif lingkungan tempat proses belajar mengajar menjadi kawasan tanpa rokok?

5. Bagaimana persepsi saudara tentang Peraturan darah Nomor 3 Tahun 2017?

6. Apakah saudara optimis Peraturan Daerah Nomor 3 Tahun 2017 akan dilaksanakan dengan baik oleh mahasiswa?

Berdasarkan hasil pengumpulan data dari penelitian ini berdasarkan daftar pertanyaan yang diajukan dapat diperoleh data kuantitaf sebagai berikut:

6 Trixie Salawati, Rizky Amalia. 2010. Perilaku Merokok di Kalangan Mahasiswa Universitas Muhammadiyah Semarang. Jurnal UNIMUS.
1. Apakah saudara mengetahui tentang Peraturan Daerah Kota Jambi yang mengatur tentang kawasan tanpa rokok?, prosentase jawaban:

a. Mengetahui : $77 \%$

b. Tidak mengetahui : $23 \%$

2. Apakah saudara mengetahui kawasan apa saja yang diatur dalam Peraturan daerah Kota Jambi Nomor 3 tahun 2017?, prosentase jawaban:

a. Mengetahui : $67,4 \%$

b. Tidak mengetahui : $32,6 \%$

3. Apakah saudara mengetahui bahwa salah satu kawasan tanpa rokok yang diatur dalam peraturan Daerah Nomor 3 Tahun 2017 adalah Lingkungan Tempat Belajar Mengajar?, prosentase jawaban:

a. Mengetahui : 80, $4 \%$

b. Tidak mengetahui : 19,6\%

4. Apakah saudara merespon dengan positif lingkungan tempat proses belajar mengajar menjadi kawasan tanpa rokok?, prosentase jawaban:

a. Merespon positif : $96 \%$

b. Tidak merespon positif : $4 \%$

5. Bagaimana persepsi saudara tentang Peraturan darah Nomor 3 Tahun 2017?, prosentase jawaban:

a. Sangat bermanfaat : $94,1 \%$

b. Kurang bermanfaat : $5,6 \%$

c. Tidak bermanfaat : $0,3 \%$

6. Apakah saudara optimis Peraturan Daerah Nomor 3 Tahun 2017 akan dilaksanakan dengan baik oleh mahasiswa?, prosentase jawaban:
a. Optimis : 60,2 \%
b. Tidak optimis : $33,9 \%$
c. Ragu-ragu : $5,9 \%$

Tingkat Pengetahuan Mahasiswa Terhadap Kota Jambi Sebagai Kawasan Tanpa Rokok Berdasarkan Peraturan Daerah Nomor 3 Tahun 2017

Kebiasaan merokok dimulai dengan adanya rokok pertama, kebiasaan merokok pada usia remaja dipengaruhi oleh orangtua, teman sebaya, kepribadian dan media informasi yang mengiklankan rokok. ${ }^{7}$ Mahasiswa merupakan salah satu komponen usia remaja yang sudah mengenal rokok. Berdasarkan jawaban yang sudah dikirim oleh mahasiswa yang berasal dari 12 Perguruan Tinggi yang ada di Kota Jambi dan beberapa kota lain di luar kota Jambi dengan jumlah responden sebanyak 322 mahasiswa, maka dapat diukur tingkat pengetahuan mahasiswa tentang Peraturan Daerah Kota Jambi Nomor 3 Tahun 2017, Mahasiswa yang sudah mengetahui telah diberlakukannya Peraturan Daerah Kota Jambi yang mengatur tentang kawasan tanpa rokok adalah sebanyak $77 \%$ dan yang tidak mengetahui adalah sebanyak $23 \%$. Jumlah mahasiswa yang sudah

7 Abdol Rahmadi, Yuniar Lestari, Yenita, Hubungan Pengetahuan dan Sikap Terhadap Rokok Dengan Kebiasaan Merokok Siswa SMP di Kota Padang, Jurnal Kesehatan Andalas 2013, Vol.2 Nomor 1, hal.26 
mengetahui kawasan apa saja yang diatur dalam Peraturan daerah Kota Jambi Nomor 3 tahun 2017 adalah sebanyak $67,4 \%$ dan yang tidak mengetahui adalah sebanyak $32,6 \%$, berkaitan dengan Lingkungan Tempat Belajar Mengajar (kampus/sekolah) sebagai kawasan tanpa rokok bahwa salah satu kawasan tanpa rokok yang diatur dalam peraturan Daerah Nomor 3 Tahun 2017 adalah sebesar 80,4\% dan yang tidak mengetahui sebanyak 19,6\%.

Dari hasil penelitian ini terlihat bahwa sebenarnya mayoritas mahasiswa di Kota Jambi sudah mengetahui telah diberlakukannya Peraturan Daerah Kota Jambi Nomor 3 Tahun 2017 Tentang Kawasan Tanpa Rokok, akan tetapi apakah mahasiswa mengetahui bahwa kawasan apa saja yang merupakan kawasan tanpa rokok menunjukkan prosentase yang lebih rendah dibandingkan pengetahuan tentang pemberlakuan peraturan daerah tersebut menunjukkan bahwa mahasiswa hanya sebatas pemberlakuan peraturan daerah saja tanpa diikuti dengan pengetahuan yang cukup tentang isi peraturan daerah tersebut. Akan tetapi mayoritas mahasiswa $(80,4 \%)$ mengetahui bahwa kampus merupakan salah satu kawasan tempat proses belajar mengajar merupakan kawasan tanpa rokok.

\section{Tingkat Persepsi Mahasiswa Terhadap Kota Jambi Sebagai Kawasan Tanpa Rokok Berdasarkan Peraturan Daerah Nomor 3 Tahun 2017}

Masyarakat telah percaya bahwa tembakau tidak merugikan kesehatan dan perokok yang telah mengalami kecanduan memandangnya sebagai sesuatu yang dapat memberikan ketenangan. ${ }^{8}$ Hal itu merupakan persepsi sebagian masyarakat yang sudah menikmati rokok sebagai bagian dari zat yang diyakini dapat memberikan ketenangan, bagaimana dengan persepsi mahasiswa tentang rokok?, Berkaitan dengan tingkat persepsi mahasiswa terhadap pemberlakuan Peraturan Daerah Nomor 3 Tahun 2017, mahasiswa diajukan 3 macam pertanyaan dengan rincian sebagai berikut; mahasiswa yang memberikan respon positif dijadikannya lingkungan tempat proses belajar mengajar sebagai kawasan tanpa rokok adalah sebesar $96 \%$ dan yang tidak memberikan respon positif adalah sebanyak $4 \%$. Berkaitan dengan persepsi mahasiswa tentang kemanfaatan pemberlakuan Peraturan darah Nomor 3 Tahun 2017 di kawasan belajar mengajar yang menilai sangat bermanfaat sebesar $94,1 \%$, yang menilai kurang bermanfaat sebesar $5,6 \%$ dan yang menyatakan tidak bermanfaat sebesar $0,3 \%$. Mahasiswa juga diajukan pertanyaan yang berkaitan dengan tingkat optimisme mahasiswa bahwa pemberlakuan Peraturan Daerah Nomor 3 Tahun 2017 akan dilaksanakan dengan baik oleh mahasiswa, 60,2 \% menyatakan optimis akan

8 Nurrahman, Pengaruh Rokok Terhadap Kesehatan dan Pembentukan Karakter Manusia, Prosiding Seminar Nasional , 2014 Volume 01 Nomor 1, hal.1 dilaksanakan dengan baik oleh mahasiswa, 33,9 \% menyatakan tidak optimis mahasiswa akan melaksanakan Peraturan Daerah ini dan 5,9 \% menyatakan ragu-ragu apakah peraturan daerah ini dapat dilaksaanakan dengan baik oleh mahasiswa atau sebaliknya.

Dari hasil penelitian ini terlihat bahwa mayoritas mahasiswa memberikan respon positif (96 \%) dijadikannya kampus sebagai salah satu kawasan tanpa rokok, demikian juga apakah pemberlakuaan lingkungan tempat belajar mengajar dijadikan sebagai kawasan tanpa rokok akan memberikan manfaat bagi mahasiswa dan lingkungannya mayoritas mahasiswa menyatakan bahwa hal ini akan memberikan penilaian "sangat bermanfaat"(94,1\%). Jika dalam masalah kemanfaatan mahasiswa memberikan penilaian sangat bermanfaat dengan pemberlakuan kampus sebagai kawasan tanpa rokok ternyata kurang signifikan dengan tingkat optimisme mahasiswa apakah hal ini dapat dilaksanakan dengan baik atau tidak, mahasiswa memberikan penilaian bahwa 33,9 \% mahasiswa masih menyatakan tidak optimis peraturan daerah ini akan dapat dilaksanakan di kawasan tempat belajar walaupun mayoritas mahasiswa masih menyatakan optimis (60,2\%). Masih tingginya angka "tidak optimis" dipicu adanya beberapa factor diantaranya:

1. Tidak adanya upaya yang massif dari pihak penyelenggara pendidikan untuk mensosialisasikaan Peraturan Daerah Kota Jambi Nomor 3 Tahun 2017 baik dalam bentuk pertemuan ilmiah maupun dalam bentuk lain seperti spanduk, banner, striker dan sebagainya;

2. Masih adanya guru, dosen, staf masih merokok di lingkungan proses bekajar mengajar;

3. Belum adanya penegakan disiplin bagi dosen, guru, staf dan mahasiswa yang melakukan pelanggaran terhadap kawasan tanpa rokok itu.

Sebagai suatu kenyataan yang ada di Indonesia bahwa Kawasan Tanpa Rokok (KTR) sudah ditetapkan, namun sampai saat ini aplikasi pelaksanaan kebijakan tersebut belum berjalan dengan baik. ${ }^{9}$ Perlu adanya upaya yang sungguh-sungguh dari semua elemen masyarakat untuk mengkampanyekan kawasan tanpa rokok ini tanpa henti, sosialisasi oleh pemerintah harus lebih diintensifkan, jika dipandang penting untuk memberikan sanksi bagi pelanggar Kawasan Tanpa Rokok (KTR).

\section{SIMPULAN}

1. Mayoritas mahasiswa di Kota Jambi memiliki tingkat Pengetahuan yang baik terhadap Kota Jambi Sebagai

${ }^{9}$ Ingan U.Tarigan, Anni Yulianti, Gambaran Kesadaran Masyarakat Terhadap Kawasan Tanpa Rokok di Indonesia, Jurnal Penelitian dan Pengembangan Pelayanan Kesehatan, Vol.3, No.2, 2019, Hal.128 
Kawasan Tanpa Rokok Berdasarkan Peraturan Daerah Nomor 3 Tahun 2017.

2. Mayoritas mahasiswa di Kota Jambi memberikan respon positif dan optimis terhadap pemberlakuan Kota Jambi Sebagai Kawasan Tanpa Rokok Berdasarkan Peraturan Daerah Nomor 3 Tahun 2017.

\section{DAFTAR PUSTAKA}

Abdol Rahmadi, Yuniar Lestari, Yenita. (2013). Hubungan Pengetahuan dan Sikap Terhadap Rokok Dengan Kebiasaan Merokok Siswa SMP di Kota Padang, Jurnal Kesehatan Andalas, Vol.2 Nomor 16

Hilda Irianty, Ridha Hayati. (2019). Gambaran Perilaku Merokok Pada Mahasiswa Fakultas Kesehatan Masyarakat (FKM) di Kampus XXX, Jurnal Manusia dan Kesehatan, Vol.2 No.2

Ingan U.Tarigan, Anni Yulianti, (2019). Gambaran Kesadaran Masyarakat Terhadap Kawasan Tanpa Rokok di Indonesia, Jurnal Penelitian dan Pengembangan Pelayanan Kesehatan, Vol.3, No.2

Komalasari D \& A.F. Helmi. 2006. Faktor-faktor Penyebab Perilaku Merokok Pada Remaja. 15 Januari 2008.

Notoatmodjo. 2003. Pendidikan dan Perilaku Kesehatan. Rineka Cipta. Jakarta.

Nurrahman. (2014) Pengaruh Rokok Terhadap Kesehatan dan Pembentukan Karakter Manusia, Prosiding Seminar Nasional, Volume 01 Nomor 1, hal.1

Ogden, Jane. 1996. Health Psychology, a tex book, Open University Press. Buckingham. Philadelphia.

Triana Srisantyorini, F.Y. Sumartin. 2005. Perilaku Merokok Mahasiswa Universitas Muhammadiyah Jakarta dan Faktor-faktor yang Memperngaruhinya Tahun 2004. Jurnal Kedokteran dan Kesehatan UMJ. Juli 2005. Vol 1 No 2.

Trixie Salawati, Rizky Amalia. 2010. Perilaku Merokok di Kalangan Mahasiswa Universitas Muhammadiyah Semarang. Jurnal UNIMUS.

Pemerintah Kota Jambi, Peraturan Daerah Kota Jambi Nomor 3 Tahun 2017 Tentang Kawasan Tanpa Rokok.

Republik Indonesia, Undang-Undang Nomor 36 Tahun 2009 Tentang Kesehatan (Lembaran Negara Republik Indonesia Tahun 2009 Nomor 144) 